\title{
Current Advances in the Development of Vaccines and Therapeutic Agents Against MERS-coV
}

\author{
Na-Rae Lee, Chae-Min Yi and Kyung-Soo Inn* \\ Department of Pharmaceutical Science, College of Pharmacy, Kyung Hee University, Seoul, Korea
}

Middle East respiratory syndrome (MERS) is an emerging infectious disease caused by the betacoronavirus (MERS$\mathrm{CoV}$ ). Since the isolation and identification of MERS-CoV in 2012, cases have been spread to neighboring nations in Arabian Peninsula area and Europe. The recent outbreak of MERS in Korea confirmed that MERS-CoV is capable of causing epidemics through person-to-person transmission. Despite of its high mortality, there is no available effective vaccine and therapeutic agent partly due to its short history. So far, ribavirin and interferon therapy has been failed to prove its efficacy in human patients. Thus, there is an urgent need for the effective countermeasures such as vaccines and therapeutics. In the current review, recent advances in the development of vaccines and therapeutic antibodies have been discussed.

Key Words: MERS, MERS-coV, Vaccine, Therapeutics

\section{INTRODUCTION}

중동호흡기증후군(Middle East respiratory syndrome, MERS)은 중동호흡기코로나바이러스(MERS-CoV)에 의 해 발병하는 급성 감염성 질환으로, 2012년 6월에 사우디 아라비아에서 처음 보고되었다. 이 후, 2015년 11월까지 1,600 명 이상의 감염자가 보고되었으며, $35 \%$ 의 치사율을 보였다 (1). 발견 이후, 중동호흡기코로나바이러스는 유럽, 아프리카, 아시아, 북아메리카 등지로 전파되는 양상을 나타냈고 $(2,3), 2014$ 년 7월까지 834명의 환자가 발생하 여(http://www.who.int/csr/don/2014 $0714 \mathrm{mers} / \mathrm{en} /$ ), 이 중 288 명이 사망하였다 $(4,5) .2015$ 년 7월에는 여행객에 의해 한국으로 전파된 중동호흡기코로나바이러스에 의해 발생 한 감염이 186 건으로 확인되었고 36 명의 환자가 사망하
였다(2015.07.15 기준). 중동호흡기코로나바이러스 감염 확 진자의 통계적 수치로 확인하였을 때, 바이러스의 감염은 모든 연령층에서 일어날 수 있으며 사망률은 나이가 많 을수록 높아지고, 36 명의 사망환자는 모두 48세 이상이 었다.

중동호흡기증후군은 2002년에 중증급성호흡기코로나바 이러스(SARS-coV)에 의해 발생하였던 중증급성호흡기증 후군과 유사한 증상을 보인다. 코로나바이러스로 분류되 며 사람에게 영향을 주는 다른 4 가지 바이러스 $(\mathrm{HCoV}-$ $\mathrm{OC} 43, \mathrm{HCoV}-229 \mathrm{E}, \mathrm{HCoV}-\mathrm{HKU} 1, \mathrm{HCoV}-\mathrm{NL} 63)$ 는 일반 감 기와 비슷한 정도의 증상만을 가지는 반면, 중증급성호흡 기코로나바이러스나 중동호흡기코로나바이러스는 하기도 에 심각한 감염을 일으키며 높은 치사율을 보인다.

질병학적으로 보면 두 바이러스는 매우 유사한 듯 하 지만, 중증급성호흡기코로나바이러스와 중동호흡기코로

Received: November 2, 2015/ Revised: November 10, 2015/ Accepted: November 12, 2015

*Corresponding author: Kyung-Soo Inn. Department of Pharmaceutical Science, College of Pharmacy, Kyung Hee University, 26 Kyungheedae-ro, Dongdaemun-gu, Seoul, 02447, Korea.

Phone: +82-2-961-0368, Fax: +82-2-966-3885, e-mail: innks@khu.ac.kr

@This is an Open Access article distributed under the terms of the Creative Commons Attribution Non-Commercial License (http://creativecommons.org/license/by-nc/3.0/). 
Table 1. Comparison between SARS-CoV and MERS-CoV

\begin{tabular}{lll}
\hline \hline & \multicolumn{1}{c}{ MERS-CoV } & \multicolumn{1}{c}{ SARS-CoV } \\
\hline First identification & 2012 & 2003 \\
First identified area & Saudi Arabia & Southern China \\
Reservoir & Dromedary camel & Bats/civets \\
Transmission & Zoonotic & Zoonotic \\
Transmission mode & Respiratory droplets/close contact & Respiratory droplets/close contact \\
Latent period & $2 \sim 15$ days & $2 \sim 14$ days \\
Lineage & Lineage C/Betacoronaviridae & Lineage B/Betacoronaviridae \\
Host receptor & DPP4 (CD26) & ACE2 \\
Infection mode & Plasma membrane fusion & Endosomal membrane fusion \\
Fatality & $>35 \%$ & $\sim 10 \%$ \\
Detection of neutralizing antibodies & Within 12 days after symptoms & $5 \sim 10$ days after symptoms \\
\hline
\end{tabular}

나바이러스는 역학적, 바이러스학적, 임상학적 측면에서 중요한 차이점을 가지고 있다(Table 1) (1).

중동호흡기코로나바이러스는 동물감염성(zoonotic) 바이 러스로, 박쥐와 낙타가 그 중간숙주로 알려져 있다. 중동 호흡기코로나바이러스는 낙타-사람 혹은 사람-사람 간 에 지속적으로 감염될 수 있으며, 2015년 한국의 경우에 서 알 수 있듯이 빠른 전파가 가능한 것으로 파악되었으 나 현재까지 사용 가능한 백신이나 효과적인 치료제가 전무한 상황으로 효과적인 백신과 치료제의 개발이 매우 시급하다.

중동호흡기코로나바이러스의 게놈은 4 개의 부속단백질 (accessory protein) 3, 4a, 4b, 5와 2개의 복제단백질(Open reading frame 1a, 1b), 그리고 4개의 구조단백질(Spike; S, Envelope; E, Nucleocapsid; N, Membrane; M)로 구성되어 있 다. 여러 단백질 중, 가장 이상적인 백신 후보로 여겨지 는 것은 $\mathrm{S}$ 단백질이다. 세포에 진입하는 첫 단계에서 $\mathrm{S}$ 단 백질은 숙주세포의 Dipeptidyl peptidase4 (DPP4)를 수용체 로 사용하여 바이러스의 세포부착에 결정적인 역할을 수 행한다 (6). 이 때, 부착되는 수용체결합도메인(receptorbinding domain, RBD)에 대한 연구도 활발히 진행되고 있 으며, S단백질의 RBD 도메인을 포함한 항원을 백신으로 사용하고자 하는 연구가 활발히 진행 중이다. 또한, 중동 호흡기코로나바이러스의 $\mathrm{S}$ 단백질은 중증급성호흡기코로 나바이러스의 S단백질과 매우 유사한 도메인 구조를 이 루고 있어(Fig. 1), 중증급성호흡기코로나바이러스에 대한
백신 연구결과들이 중동호흡기코로나바이러스 백신개발 연구에 유용한 기반지식을 제공하고 있다. 본 종설에서는 아직 초기단계이기는 하지만 현재까지 진행되고 있는 중 동호흡기증후군 예방 및 치료를 위한 백신과 치료제 개발 동향을 조사하였다.

1. 백신

1) 중동호흡기코로나바이러스의 사백신과 약독화 백신 중동호흡기증후군 바이러스의 경우 짧은 연구기간 및 고위험성으로 인한 연구의 어려움 등으로 인해 높은 면 역원성(immunogenicity)을 가지는 사백신 혹은 약독화 백 신의 개발 연구는 매우 미진한 상황이다. 중증호흡기 바 이러스의 경우, $\beta$-propiolactone을 이용한 사백신을 $\mathrm{Balb} / \mathrm{C}$ 마우스에 투여하여 혈청 내 중화항체 생성을 확인한 결 과가 보고된 바 있으며, 특히 마우스 모델에서 S단백질의 $\mathrm{RBD}$ 도메인에 대한 항체가 형성되고 바이러스 수용체인 ACE2 (angiotensin-converting enzyme 2)와 RBD 도메인과 의 결합을 억제하여 혈청 내 바이러스의 양이 대조군에 비해 약 $50 \%$ 감소되는 것이 확인되었다 (7). 또한, 이러 한 $\beta$-propiolactone을 이용한 중증호흡기바이러스 사백신 은 S단백질과 N단백질을 이용한 아데노-중증호흡기코로 나바이러스 백신보다(adeno-associated vaccine) 바이러스의 중식을 효과적으로 저해시키는 것으로 보고되었다 (8). 현재까지 중동호흡기코로나바이러스에 대한 사백신에 대 한 보고는 없지만 이러한 중증호흡기증후군 바이러스의 


\section{SARS-CoV}

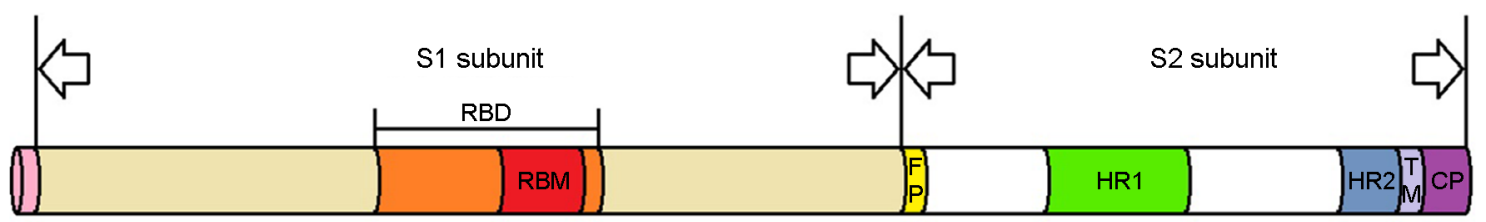

MERS-CoV S

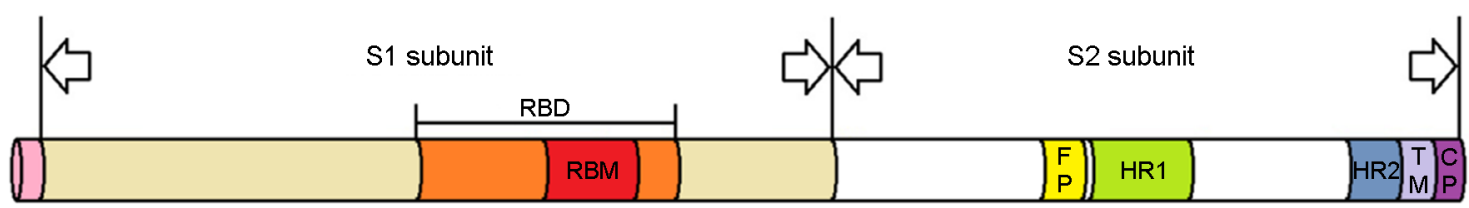

Figure 1. Schematic diagrams for S protein domain structures of SARS-coV and MERS-coV

예에서 중동호흡기증후군의 경우도 사백신이 우수한 중 화항체능을 가질 수 있을 것임이 예상된다.

약독화된 바이러스를 통한 중동호흡기증후군 백신의 개발은 bacterial artificial chromosome (BAC) 시스템을 이 용하여 돌연변이주를 제조한 재조합(recombinant) 중동호 흡기코로나바이러스가 주로 시도되고 있다. 부속단백질 $3,4 \mathrm{a}, 4 \mathrm{~b}, 5$ 가 결핍된 변이바이러스는 Huh-7과 Vero A66 에서 RNA 증폭이 야생바이러스와 유사한 수준으로 일어 났으며, 세포 내 바이러스 증식이 야생바이러스 수준으 로 확인되었다. 반면, 중동호흡기코로나바이러스의 $\mathrm{E}$ 단백 질 유전자를 제거한 재조합-중동호흡기코로나바이러스 (recombinant-MERS-CoV $\Delta \mathrm{E}$ )는 Huh-7과 Vero A66 세포주에 서 정상적으로 RNA 복제가 일어나지만, 성장속도가 현저 하게 감소되는 것이 확인되었으며, CPE (cytopathic effect) 현상도 감소되었다 (9). 이러한 E단백질 변이 재조합 중 동호흡기코로나바이러스는 약독화 바이러스 백신으로 개 발 가능성을 보여주었지만, 생체 내(in vivo) 모델에서는 아직 확인된 바가 없어 사백신과 약독화 바이러스 백신 에 대한 연구가 추가적으로 요구되고 있다.

\section{2) DNA 백신}

중증급성호흡기코로나바이러스의 경우 $\mathrm{S}$ 단백질을 인코 딩하는 DNA 백신을 쥐에게 투여하였을 때, 중화항체와 $\mathrm{T}$ 세포 면역을 유도하며, 중증급성호흡기코로나바이러스 로 면역화 후 감염시켰을 때 생존률을 높일 수 있음이 보고된 바 있다 (10). 또한, $\mathrm{RBD}$ 를 포함하는 $\mathrm{S} 1$ 부분만을
인코딩하는 DNA 백신을 투여하였을 때, 체액성 면역반 응과 $\mathrm{T}$ 세포 매개성 면역반응이 모두 유도됨이 확인되었 다 (11). 현재 중동호흡기코로나바이러스의 DNA 백신의 표적으로는 $\mathrm{DPP} 4$ 에 결합하여 세포 내 침투를 유도하는 $\mathrm{S}$ 단백질이 주로 후보단백으로 연구에 사용되고 있다 (6). 중증급성호흡기코로나바이러스 DNA 백신과 마찬가지로, 중동호흡기코로나바이러스의 DNA 백신 또한 면역을 유 도할 수 있다는 점이 확인되었다. 쥐와 영장류에서 감마 인터페론(IFN- $\gamma$ )을 확인함으로써 강력한 $\mathrm{T}$ 세포 면역을 증명하였고, 세포 내의 사이토카인을 통해 $\mathrm{CD} 4$ 와 $\mathrm{CD} 8 \mathrm{~T}$ 세포의 작용을 확인하였다. 또한, 백신 접종(vaccination)을 실시한 쥐와 영장류, 낙타 모두에게서 체액성 면역반응이 발생한다는 사실도 확인되었다 (12). 하지만, 중증급성호 흡기코로나바이러스나 중동호흡기코로나바이러스 모두 $\mathrm{DNA}$ 백신 단독투여 시, 약독화 생백신 같은 다른 백신의 형태를 투여하였을 때보다 면역원성이 낮아서 면역 효율 (immune efficacy)을 높이는 다른 방안이 필요하다. 따라서 중동호흡기코로나바이러스 백신 개발의 전략으로 DNA 백신을 선택하는 경우 일차 백신 접종(priming boost)을 다 른 형태로 유도하거나 다른 백신과 병용투여하여 투여하 는 등 면역원성을 높이는 방법이 고안되어야 할 것이다.

3) 단백질 아단위 백신(Subunit vaccine)

재조합 단백질을 사용한 아단위 백신의 경우에도 $\mathrm{S}$ 단 백질이 주요 백신 후보로 연구되고 있다. 중동호흡기코 로나바이러스와 같은 코로나바이러스 계열인 중증호흡 
기코로나바이러스의 $\mathrm{S}$ 단백질은 5 개의 면역우성 도메인 (immunodominant domain)을 가지고 있어, 전체 $\mathrm{S}$ 단백질을 이용한 백신은 이러한 면역우성 도메인에 의해 너무 강력 한 면역반응을 유도하거나 antibody-mediated enhancement effect $(\mathrm{ADE})$ 반응을 일으킬 수 있는 위험성이 있는 것으 로 보고된 바 있어 다양한 $\mathrm{S}$ 단백질의 일부만을 포함하는 아단위 백신에 대한 연구가 진행되고 있다 (13). S단백질 의 아미노산 $358-588,367-588,377-588,367-606$ 의 4 가지 $\mathrm{RBD}$ 를 포함하는 아단위 백신 후보에 대한 연구결과들이 보고되었으며 (14 18), 358-588, 377-662 RBD의 주입은 마 우스와 토끼 모델에서 중화항체를 형성시키는 것을 확인 하였다 $(15,19)$. 이러한 RBD 포함 아단위 백신의 면역원 성을 높이기 위해 다양한 시도들이 이루어졌는데, 사람의 $\mathrm{IgG}-\mathrm{Fc}$ 와 중동호흡기코로나바이러스의 $\mathrm{S}$ 단백질의 $\mathrm{RBD}$ 도메인을 결합시켜 면역원성을 증가시키면서 백신의 생 산성과 정제에 용이한 방법이 고안되었다. 이러한 아단위 백신들 중에서 S377-588-Fc는 수용액상태의 DPP4와 세포 에 발현되어 있는 DPP4 모두와 결합력이 가장 높으면서 마우스와 토끼 모델에서 중동호흡기코로나바이러스에 대 한 혈청 내 $\mathrm{IgG}$ 의 양을 효과적으로 증가시키면서 중화항 체의 양을 가장 많이 증가시키는 것으로 확인되었다 (16, 20). 또한, MERS-CoV-RBD-Fc 백신은 비강주사(intranasal injection)으로 주입했을 때 피하주사(subcutaneous injection) 보다 폐에서의 $\mathrm{IgA}$ 의 양과 중화항체의 양이 더 증가되었 다. 또한, $\mathrm{S}$ 단백질에 대해 특이적으로 인터루킨2와 감마인 터페론을 생성하는 $\mathrm{T}$ 세포의 양과 혈청 내 중화항체 양이 더 증가되는 현상이 보고되었다 (21). 이는 비강 내 백신 접종을 통해 더 효과적으로 중동호흡기코로나바이러스에 대한 $\mathrm{T}$ 세포, $\mathrm{B}$ 세포 반응을 빠르게 유도할 수 있음을 의 미한다. 그밖에 Baculovirus insect cell expression 시스템을 이용하여 재조합 중동호흡기코로나바이러스의 $\mathrm{S}$ 단백질을 생산하여 크기가 $25 \mathrm{nM}$ 이하인 나노입자형태 백신이 개 발되었는데, 이 S-나노입자(S-nanoparitcle) 역시 마우스 모 델에서 중화항체 생산을 효과적으로 유도함이 확인되었 다 (22).

4) 바이러스 벡터 백신

바이러스 벡터는 중증급성호흡기코로나바이러스를 비 롯한 여러 바이러스 감염에 대한 백신후보개발에 중요한 전달 매개체로서 여러 연구에 사용되어 왔다. 중증급성 호흡기코로나바이러스 백신 개발에는 modified vaccinia virus Ankara (MVA), vesicular stomatitis virus, rhabdovirus, adenovirus, adeno-associated virus 등이 사용되고 있다. 중증 호흡기코로나바이러스의 S단백질을 기본으로 만든 MVAbased 백신을 투여한 쥐의 경우, 면역화 후 감염하였을 때, 중화항체를 유도하는 것이 확인되었다 (23). 또한, 중 증급성호흡기코로나바이러스의 $\mathrm{S} 1, \mathrm{M}, \mathrm{NP}$ 단백질을 인코 딩하는 adeno-based 백신을 투여한 원숭이에서 강력한 중 화항체 유도와 $\mathrm{T}$ 세포 면역반응이 관찰되었다 (24). 중증 급성호흡기코로나바이러스의 $\mathrm{RBD}$ 를 발현하는 Adenoassociated virus-based 백신의 경우에도 세포성 면역과 체 액성 면역을 유도할 수 있다는 연구결과 또한 보고되었 으며, 이러한 점에 착안하여, 중동호흡기코로나바이러스의 viral vector-based 백신 연구도 활발히 진행되고 있다. MVA 벡터에 중동호흡기코로나바이러스의 S단백질을 발현시킨 백신을 투여한 쥐에서 중화항체가 생성되었으며 $\mathrm{T}$ 세포 반응이 활성화 됨이 보고되었다 (25). MVA 벡터에 중동호 흡기코로나바이러스의 S단백질을 포함하는 MVA 백신을 $\mathrm{BALB} / \mathrm{c}$ 마우스에 근육주사(Intramuscular infection), 혹은 피하주사(subcutaneous injection)로 단회투여 및 반복투여로 실시하면 $\mathrm{S}$ 단백질 특이적인 항체가 형성될 뿐만 아니라, $\mathrm{S}$ 단백질 중 S291 (KYYSIIPHSI), S823 (EYGQFCSKI) 펩 티드를 항원결정기(epitope)로 인지하는 $\mathrm{S}$ 단백질 특이적인 $\mathrm{CD} 8 \mathrm{~T}$ 세포가 생성되는 것이 관찰되었다. 또한, 이를 다 시 확인하기 위하여 S291 펩티드로 세포 내 자극실험을 한 결과, 이에 특이적인 $\mathrm{CD} 8 \mathrm{~T}$ 세포가 활성화됨을 증명 하였다.

또 다른 연구로는 중동호흡기코로나바이러스의 S단 백질의 S1 아단위를 Adenovirus type 5나 41에 발현시킨 adeno-based 백신을 쥐에 투여한 보고가 있다 (26). Adenovirus type 5나 41을 위내투여(intragastric injection) 혹은 근 육주사(intramuscular injection)한 결과, 모든 경우에서 RBD 특이적인 $\mathrm{IgG}$ 항체생성이 유도되었다. 이 결과는 4주의 단기간 실험과 16 주의 장기간 실험 모두에서 유효했으며 이는 백신화 후 장시간이 지나도 항체가 남아있어 백신 으로의 가능성을 확인할 수 있는 결과였다. 또, 근육주사 로 백신화한 마우스의 경우, 4주는 물론 16주 이후까지 감마인터페론을 발현하는 CD8 T 세포를 관찰할 수 있었 으며, 이는 Adenovirus 백신이 체액성 면역뿐만 아니라 세포성 면역까지 유도가 가능하다는 것을 나타내 향후 중동호흡기증후군 백신으로 사용될 수 있는 가능성을 보 여주었다. 


\section{2. 치료전략의 개발}

중동호흡기코로나바이러스는 높은 치사율임에도 불구 하고 현재 승인된 치료제는 없는 상태로 다양한 치료법 및 치료제의 개발이 진행 중이다. 원숭이(rhesus macaque) 모델에서 중동호흡기코로나바이러스를 감염시킨 후, 바이 러스 치료제인 리바비린과 알파인터페론을 병용투여 하 였을 때, 바이러스의 유전자 증폭이 감소되고 폐 조직의 염증반응이 감소되어 약물치료를 하지 않은 대조군에 비 해 병의 진행이 약화된 것을 확인하였다 (27). 하지만, 중 동호흡기증후군이 나타난 환자군에서 인터페론과 리바비 린을 병용투여한 경우 일부 환자에게서는 효과적으로 병 원성이 감소되었지만, 대체적으로 미비한 효과를 보여 새 로운 약물의 개발이 중요성을 드러냈다. 중증급성호흡기 증후군환자의 경우 $\mathrm{S}$ 단백질을 중화시키는 단일클론항체 주입이 중증급성호흡기바이러스 성장을 저해하는 것이 확인되었다. 따라서, 중동호흡기코로나바이러스에서도 $\mathrm{S}$ 단백질의 $\mathrm{RBD}$ 도메인에 결합하는 중화항체 개발이 이루 어지고 있다. Non-immune human Ab-phage library 스크리 닝을 통한 인간 단일클론항체 개발 연구에서는 중동호흡 기코로나바이러스의 $\mathrm{S}$ 단백질에 대한 단일사슬항체 $(\mathrm{ScFv})$ 를 확보하였고 이 항체들이 $\mathrm{RBD}$ 와 $\mathrm{DPP} 4$ 사이의 결합을 억제하는 것이 확인되었다. 일부 항체는 나노몰 이하의 높은 결합력을 가지는 것을 확인하였지만, $\mathrm{S}$ 단백질의 변 이에 따라 중화를 시키지 못할 가능성을 시사하였다 (28). 또한, IgM Fab library를 이용하여 개발된 m336 항체는 $\mathrm{RBD}$ 와 $\mathrm{DPP} 4$ 의 결합을 경쟁적으로 억제할 수 있음이 확 인되었고, 이는 결정화스크리닝(crystallization screening)을 통해 증명되었다 (29). 또한 중동호흡기코로나바이러스에 감염된 환자의 $\mathrm{B}$ 세포로부터 $\mathrm{S}$ 단백질을 중화시킬 수 있 는 단일항체를 생성하는 연구도 진행되었으며, 이 LCA60 는 기존에 알려진 $3 \mathrm{~B} 11$ 항체에 비해 높은 중화능을 가짐 이 확인되었다 (30). LCA60 항체를 중동호흡기코로나바이 러스 감염 전이나 감염 후에 주입했을 때 모두 바이러스 중화를 시킬 수 있음을 마우스 모델에서 확인하였다. 이 외에도 중동호흡기코로나바이러스를 중화할 수 있는 다 양한 항체를 개발 중이지만, 아직 임상실험에 들어간 단 일클론항체 후보물질은 없는 상태이다.

\section{CONCLUSIONS}

2012년 처음 확인된 중동호흡기증후군은 지속적으로 발생국가와 환자수가 증가하고 있는 패턴을 나타내고 있 어 현재 26 개국에서 1,600 명 이상이 확진되었고 이 중 575 명의 사망자가 발생하여 전세계적인 주목을 받고 있 는 신종 감염질환이다. 기존에는 사람간 전파확률이 낮은 것으로 알려져 있었으나 2015년 한국에 전파되어 대규모 사람간 전파가 가능함이 확인되었고 막대한 국가적 손실 을 초래하였다. 따라서 이를 예방하고 치료할 수 있는 백신 및 치료제의 개발이 매우 시급하다고 할 수 있다.

현재까지의 연구는 짧은 연구기간 및 고병원성 병원체 연구의 어려움으로 인해 많은 진전이 이루어지지는 못하 고 있는 상황이다. 백신관련 연구는 앞서 기술한 바와 같 이 주로 $\mathrm{S}$ 단백질에 한정되어 이루어지고 있으며 이는 중 화항체 형성에는 효과적인 전략으로 생각되나 $\mathrm{T}$ 세포성 면역반응 유도에 관해서는 추가적인 연구결과가 요구되 고 있다. 특히 환자로부터의 임상시료 분석과 임상적 중 증도와의 상관관계 분석을 통해 가장 효과적인 방어 면 역을 유도할 수 있는 항원의 결정 및 백신의 개발이 필 수적이다. 치료제의 경우 현재까지는 주로 $\mathrm{S}$ 단백질과 결 합하여 바이러스의 감염을 억제할 수 있는 단일클론항체 의 개발이 주로 시도되고 있으며 향후 스크리닝을 통해 바이러스를 억제할 수 있는 다양한 화합물의 도출이 진 행되어야 할 것이다.

\section{REFERENCES}

1) Chan JF, Lau SK, To KK, Cheng VC, Woo PC, Yuen KY. Middle East respiratory syndrome coronavirus: another zoonotic betacoronavirus causing SARS-like disease. Clin Microbiol Rev 2015;28:465-522.

2) Cheng VC, Lau SK, Woo PC, Yuen KY. Severe acute respiratory syndrome coronavirus as an agent of emerging and reemerging infection. Clin Microbiol Rev 2007;20:660-94.

3) Zaki AM, van Boheemen S, Bestebroer TM, Osterhaus AD, Fouchier RA. Isolation of a novel coronavirus from a man with pneumonia in Saudi Arabia. N Engl J Med 2012;367:1814-20.

4) Gulland A. WHO voices concern over rising numbers of MERS-CoV cases. BMJ 2014;348:g2968.

5) Kupferschmidt K. Emerging diseases. Soaring MERS cases in 
Saudi Arabia raise alarms. Science 2014;344:457-8.

6) Raj VS, Mou H, Smits SL, Dekkers DH, Müller MA, Dijkman $\mathrm{R}$, et al. Dipeptidyl peptidase 4 is a functional receptor for the emerging human coronavirus-EMC. Nature 2013;495:251-4.

7) He Y, Zhou Y, Siddiqui P, Jiang S. Inactivated SARS-CoV vaccine elicits high titers of spike protein-specific antibodies that block receptor binding and virus entry. Biochem Biophys Res Commun 2004;325:445-52.

8) See RH, Zakhartchouk AN, Petric M, Lawrence DJ, Mok CP, Hogan RJ, et al. Comparative evaluation of two severe acute respiratory syndrome (SARS) vaccine candidates in mice challenged with SARS coronavirus. J Gen Virol 2006;87:641 -50 .

9) Almazán F, DeDiego ML, Sola I, Zuñiga S, Nieto-Torres JL, Marquez-Jurado S, et al. Engineering a replication-competent, propagation-defective Middle East respiratory syndrome coronavirus as a vaccine candidate. MBio 2013;4:e00650-13.

10) Yang ZY, Kong WP, Huang Y, Roberts A, Murphy BR, Subbarao $\mathrm{K}$, et al. A DNA vaccine induces SARS coronavirus neutralization and protective immunity in mice. Nature 2004;428:561 -4 .

11) Zhao B, Jin NY, Wang RL, Zhang LS, Zhang YJ. Immunization of mice with a DNA vaccine based on severe acute respiratory syndrome coronavirus spike protein fragment 1 . Viral Immunol 2006;19:518-24.

12) Muthumani K, Falzarano D, Reuschel EL, Tingey C, Flingai $\mathrm{S}$, Villarreal DO, et al. A synthetic consensus anti-spike protein DNA vaccine induces protective immunity against Middle East respiratory syndrome coronavirus in nonhuman primates. Sci Transl Med 2015;7:301ra132.

13) Weingartl H, Czub M, Czub S, Neufeld J, Marszal P, Gren J, et al. Immunization with modified vaccinia virus Ankara-based recombinant vaccine against severe acute respiratory syndrome is associated with enhanced hepatitis in ferrets. J Virol 2004; 78:12672-6.

14) Lu G, Hu Y, Wang Q, Qi J, Gao F, Li Y, et al. Molecular basis of binding between novel human coronavirus MERS-CoV and its receptor CD26. Nature 2013;500:227-31.

15) Mou H, Raj VS, van Kuppeveld FJ, Rottier PJ, Haagmans BL, Bosch BJ. The receptor binding domain of the new Middle East respiratory syndrome coronavirus maps to a 231-residue region in the spike protein that efficiently elicits neutralizing antibodies. J Virol 2013;87:9379-83.

16) Du L, Kou Z, Ma C, Tao X, Wang L, Zhao G, et al. A truncated receptor-binding domain of MERS-CoV spike protein potently inhibits MERS-CoV infection and induces strong neutralizing antibody responses: implication for developing therapeutics and vaccines. PLoS One 2013;8:e81587.

17) Chen Y, Rajashankar KR, Yang Y, Agnihothram SS, Liu C, Lin YL, et al. Crystal structure of the receptor-binding domain from newly emerged Middle East respiratory syndrome coronavirus. J Virol 2013;87:10777-83.

18) Wang $N$, Shi X, Jiang L, Zhang S, Wang D, Tong $P$, et al. Structure of MERS-CoV spike receptor-binding domain complexed with human receptor DPP4. Cell Res 2013;23:986-93.

19) Du L, Zhao G, Kou Z, Ma C, Sun S, Poon VK, et al. Identification of a receptor-binding domain in the $\mathrm{S}$ protein of the novel human coronavirus Middle East respiratory syndrome coronavirus as an essential target for vaccine development. J Virol 2013;87:9939-42.

20) Ma C, Wang L, Tao X, Zhang N, Yang Y, Tseng CT, et al. Searching for an ideal vaccine candidate among different MERS coronavirus receptor-binding fragments--the importance of immunofocusing in subunit vaccine design. Vaccine 2014; 32:6170-6.

21) Ma C, Li Y, Wang L, Zhao G, Tao X, Tseng CT, et al. Intranasal vaccination with recombinant receptor-binding domain of MERS-CoV spike protein induces much stronger local mucosal immune responses than subcutaneous immunization: Implication for designing novel mucosal MERS vaccines. Vaccine 2014;32:2100-8.

22) Coleman CM, Liu YV, Mu H, Taylor JK, Massare M, Flyer DC, et al. Purified coronavirus spike protein nanoparticles induce coronavirus neutralizing antibodies in mice. Vaccine 2014;32:3169-74

23) Bisht H, Roberts A, Vogel L, Bukreyev A, Collins PL, Murphy $\mathrm{BR}$, et al. Severe acute respiratory syndrome coronavirus spike protein expressed by attenuated vaccinia virus protectively immunizes mice. Proc Natl Acad Sci U S A 2004;101:6641-6.

24) Gao W, Tamin A, Soloff A, D'Aiuto L, Nwanegbo E, Robbins $\mathrm{PD}$, et al. Effects of a SARS-associated coronavirus vaccine in monkeys. Lancet 2003;362:1895-6.

25) Song F, Fux R, Provacia LB, Volz A, Eickmann M, Becker S, et al. Middle East respiratory syndrome coronavirus spike protein delivered by modified vaccinia virus Ankara efficiently induces virus-neutralizing antibodies. J Virol 2013;87:11950-4.

26) Kim E, Okada K, Kenniston T, Raj VS, AlHajri MM, Farag EA, et al. Immunogenicity of an adenoviral-based Middle 
East Respiratory Syndrome coronavirus vaccine in BALB/c mice. Vaccine 2014;32:5975-82.

27) Falzarano D, de Wit E, Rasmussen AL, Feldmann F, Okumura A, Scott DP, et al. Treatment with interferon-alpha2b and ribavirin improves outcome in MERS-CoV-infected rhesus macaques. Nat Med 2013;19:1313-7.

28) Tang XC, Agnihothram SS, Jiao Y, Stanhope J, Graham RL, Peterson EC, et al. Identification of human neutralizing antibodies against MERS-CoV and their role in virus adaptive evolution. Proc Natl Acad Sci U S A 2014;111:E2018-26.

29) Ying T, Prabakaran P, Du L, Shi W, Feng Y, Wang Y, et al. Junctional and allele-specific residues are critical for MERS$\mathrm{CoV}$ neutralization by an exceptionally potent germline-like antibody. Nat Commun 2015;6:8223.

30) Corti D, Zhao J, Pedotti M, Simonelli L, Agnihothram S, Fett $\mathrm{C}$, et al. Prophylactic and postexposure efficacy of a potent human monoclonal antibody against MERS coronavirus. Proc Natl Acad Sci U S A 2015;112:10473-8. 